Reflections on Poetry 



\section{Reflections on Poetry}

\section{ALEXANDER GOTTLIEB BAUMGARTEN'S}

Meditationes philosophicae

de nonnullis

ad poema pertinentibus

Translated, with the Original Text, an Introduction, and Notes, by

KARL ASCHENBRENNER

and

WILLIAM B. HOLTHER

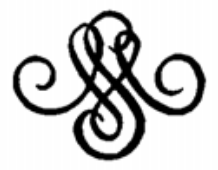

UNIVERSITY OF CALIFORNIA PRESS

Berkeley and Los Angeles: 1954 
UNIVERSITY OF CALIFORNIA PRESS

BERKELEY AND LOS ANGELES

CALIFORNIA

\section{CAMBRIDGE UNIVERSITY PRESS}

LONDON, ENGLAND

COPYRIGHT, 1954, BY

THE REGENTS OF THE UNIVERSITY OF CALIFORNIA

PRINTED IN THE UNITED STATES OP AMEAICA

QY THE UNIVERSITY OF CALIFORN1A PRINTING DEPARTMENT

L. C. CATALOG CARD NO. 54-6475

DESIGNED BY ADRIAN WILSON 